Original Research Article

\title{
An experimental study to investigate the effects of venlafaxine and escitalopram on anticonvulsant activity of conventional antiepileptic drugs in mice
}

\author{
Santosh Kumar Singh ${ }^{1 *}$, Anamika Singh ${ }^{2}$
}

\begin{abstract}
${ }^{1}$ Department of Pharmacology, Armed Forces Medical College, Pune, Maharashtra, India ${ }^{2}$ Department of Oral Medicine and Radiology, Dr. D.Y. Patil Dental College and Hospital Pimpri, Pune, Maharashtra, India
\end{abstract}

Received: 25 April 2017 Accepted: 24 May 2017

*Correspondence to: Dr. Santosh Kumar Singh, Email: santyafmc@gmail.com

Copyright: () the author(s), publisher and licensee Medip Academy. This is an openaccess article distributed under the terms of the Creative Commons Attribution NonCommercial License, which permits unrestricted noncommercial use, distribution, and reproduction in any medium, provided the original work is properly cited.

\begin{abstract}
Background: Depression is a common psychiatric comorbidity in patients with epilepsy which remains often untreated, due to concern of antidepressant induced seizures. The safety status of selective serotonin reuptake inhibitors (SSRIs) in epileptics is controversial.

Methods: Phase I acute effect of venlafaxine and escitalopram on the seizure threshold was studied. Phase II, the acute effects of test ADDs on the effective dose of AEDs viz valproate, phenobarbitone and phenytoin were studied in maximal electroshock (MES). Phase III- same study design as in phase II except that AEDs and ADDs were administered daily for 28 days.

Results: Venlafaxine raised the electroconvulsive threshold in a dose dependant manner in phase I, however it was significant at a dose of $25 \mathrm{mg} / \mathrm{kg}$. In phase II, a significant reduction in ED50 of valproate was observed when it was coadministered with venlafaxine at dose of 12.5 and $25 \mathrm{mg} / \mathrm{kg}$, whereas ED50 of phenobarbitone was significantly reduced at a dose of $25 \mathrm{mg} / \mathrm{kg}$. Chronic administration of venlafaxine at $12.5 \mathrm{mg} / \mathrm{kg}$ daily reduced ED50 of valproate. At $25 \mathrm{mg} / \mathrm{kg}$ daily ED50 of all the three studied AEDs was reduced, Escitalopram $8 \mathrm{mg} / \mathrm{kg}$ significantly raised the electroconvulsive threshold value in phase 1 , Escitalopram administered in the dose of $8 \mathrm{mg} / \mathrm{kg}$ reduced the ed50 value of valproate. Escitalopram given in dose of 4 and $8 \mathrm{mg} / \mathrm{kg}$ reduced the ED50 value of valproate.

Conclusions: From this finding, it may be concluded that venlafaxine and escitalopram administered either alone or in combination with AEDs acutely or chronically, exhibit anticonvulsant action.
\end{abstract}

Keywords: Antiepileptics, Antidepressants, Maximal electroshock, Seizures, Seizure threshold

\section{INTRODUCTION}

Depression is a common psychiatric comorbidity in patients of epilepsy, manifesting clinically in $66 \%$ of the patients. ${ }^{1}$ Co-morbid depression is associated with high rates of suicides, poor quality of life and poor prognosis. ${ }^{2}$ Epilepsy patients who are diagnosed with clinical depression are often untreated, due to concern of antidepressant induced seizures. ${ }^{3-5}$ Estimates of the incidence of antidepressant related seizures range from 0.1 to $4.0 \%{ }^{5}$

Tricyclic antidepressants (TCAs) may trigger seizures because of their local anesthetic, antihistaminic, and antimuscarinic properties. ${ }^{4}$ The safety status of selective serotonin reuptake inhibitors (SSRIs) in epileptics is controversial. Some animal studies had shown enhancement of anticonvulsant action of conventional antiepileptic drugs (AEDs) by fluoxetine on acute and chronic administration. ${ }^{6,7}$ However, another study shows that chronic fluoxetine has no anticonvulsant property. ${ }^{8}$ Atypical antidepressant, mianserin has pro as well as anticonvulsant activity depending on its duration of administration. ${ }^{9}$ In recent studies, venlafaxine which is a serotonin norepinephrine reuptake inhibitor (SNRI) has shown anticonvulsant property in maximal electroshock model in mice and rats. ${ }^{10-12}$ However another study shows that high doses of venlafaxine may be proconvulsant in 
pentylenetetrazole (PTZ) induced seizure model in mice. ${ }^{13}$ There is limited data available on the effect of escitalopram on seizure threshold. In a study escitalopram was found to have proconvulsant property in picrotoxin induced convulsion in mice. Studies on citalopram had shown anticonvulsant property in both animal and human studies. $^{14,15}$

Aim of the study was to an experimental study to investigate the effects of venlafaxine and escitalopram on anticonvulsant activity of conventional antiepileptic drugs in mice.

\section{METHODS}

The experiment complied with the guidelines for animal experimentation of our laboratory and was conducted in Department of Pharmacology.

\section{Animals}

Healthy adult Swiss albino male mice weighing 20-30g were used in this study. The mice were fed on standard laboratory diet and water ad libitum. The study was conducted in compliance with Committee for the purpose of Control and Supervision on Experiments on Animals (CPCSEA) guidelines. ${ }^{16}$

\section{Drugs and chemicals}

\section{Venlafaxine hydrochloride}

Venlafaxine hydrochloride was suspended in $1 \%$ gum acacia to prepare a suspension of $2 \mathrm{mg} / \mathrm{ml}$, and administered orally in doses of $6.25,12.5$ and $25 \mathrm{mg} / \mathrm{kg}$.

\section{Escitalopram oxalate}

Escitalopram oxalate was suspended in $1 \%$ gum acacia to prepare a suspension of $0.6 \mathrm{mg} / \mathrm{ml}$. It was administered orally in doses of 2,4 and $8 \mathrm{mg} / \mathrm{kg}$.

\section{Phenytoin sodium}

Phenytoin sodium was suspended in $1 \%$ gum acacia to prepare a suspension of $1.5 \mathrm{mg} / \mathrm{ml}$ and administered orally in doses of 5,10 and $20 \mathrm{mg} / \mathrm{kg}$.

\section{Phenobarbitone sodium}

Phenobarbitone sodium was suspended in $1 \%$ gum acacia to prepare a suspension of $1.5 \mathrm{mg} / \mathrm{ml}$ of phenobarbitone. It was administered orally in doses of 5,10 and $20 \mathrm{mg} / \mathrm{kg}$ to experimental animals.

\section{Sodium valproate}

Sodium valproate was dissolved in distilled water to prepare a solution of $30 \mathrm{mg} / \mathrm{ml}$, and administered orally in doses of 100, 200 and $400 \mathrm{mg} / \mathrm{kg}$ to experimental animals.

Experimental design of the study was carried out in the following three phases.

\section{Phase I}

In phase I, acute effect of venlafaxine and escitalopram on the seizure threshold was studied. ADDs were given in three doses once, using 4 groups of 6 mice each per dose of ADD (i.e. total 24 mice per dose of ADD). Venlafaxine was given in the doses of $6.25,12.5$, and $25 \mathrm{mg} / \mathrm{kg}$ and escitalopram was given in doses of 2,4 , and $8 \mathrm{mg} / \mathrm{kg}$ to the assigned groups. The control group for both the studied ADDs comprised of 4 groups of 6 mice each and was treated with vehicle (1\% gum acacia) alone (Table 1). Each group was exposed to different intensity of electric current i.e. $6,8,10$ and $12 \mathrm{~mA}$. The number of animals convulsing at each current intensity was noted. CS50 (current strength necessary to induce tonic hind limb extension in $50 \%$ of the animals) along with its standard error of mean (SEM) was calculated for control and various treatment groups by the method of Miller and Tainter. ${ }^{17}$ Increase/ decrease in the CS50 value of the treatment group were observed and CS50 of various treatment groups were compared with control group.

Table 1: Study design for phase II and phase III studies.

\begin{tabular}{|c|c|c|c|c|c|c|c|c|c|c|}
\hline \multirow{3}{*}{\multicolumn{2}{|c|}{$\begin{array}{l}\text { ADDs and their } \\
\text { Dose (mg/kg) }\end{array}$}} & \multicolumn{9}{|c|}{ Number of animals for various AED groups and AED doses used } \\
\hline & & \multicolumn{3}{|l|}{ VPA } & \multicolumn{3}{|l|}{ PB } & \multicolumn{3}{|l|}{ PHT } \\
\hline & & $100 \mathrm{mg} / \mathrm{kg}$ & $200 \mathrm{mg} / \mathrm{kg}$ & $400 \mathrm{mg} / \mathrm{kg}$ & $5 \mathrm{mg} / \mathrm{kg}$ & $10 \mathrm{mg} / \mathrm{kg}$ & 20mg/kg & $5 \mathrm{mg} / \mathrm{kg}$ & $10 \mathrm{mg} / \mathrm{kg}$ & $20 \mathrm{mg} / \mathrm{kg}$ \\
\hline \multirow{3}{*}{ VLF } & 6.25 & 6 & 6 & 6 & 6 & 6 & 6 & 6 & 6 & 6 \\
\hline & 12.5 & 6 & 6 & 6 & 6 & 6 & 6 & 6 & 6 & 6 \\
\hline & 25 & 6 & 6 & 6 & 6 & 6 & 6 & 6 & 6 & 6 \\
\hline \multirow{3}{*}{ ESC } & 2 & 6 & 6 & 6 & 6 & 6 & 6 & 6 & 6 & 6 \\
\hline & 4 & 6 & 6 & 6 & 6 & 6 & 6 & 6 & 6 & 6 \\
\hline & 8 & 6 & 6 & 6 & 6 & 6 & 6 & 6 & 6 & 6 \\
\hline Control & Vehicle & 6 & 6 & 6 & 6 & 6 & 6 & 6 & 6 & 6 \\
\hline
\end{tabular}

VPA: sodium valproate, PB: phenobarbitone, PHT: phenytoin, VLF: venlafaxine, ESC: escitalopram, ADD: antidepressant drug 


\section{Phase II}

In phase II, the acute effects of test ADDs on the effective dose of AEDs viz valproate, phenobarbitone and phenytoin were studied in maximal electroshock (MES). For each ADD and AED combination, total of 9 groups of 6 mice each received both the drugs in various combinations as per Table 1. The controls for each AED were formed by 3 groups of 6 animals each; each control subgroup received different dose of AED only as drug treatment (Table 1). The animals were given MES and the number of animals protected against MES was recorded for each group. The protective efficacy of antiepileptic drugs was expressed as median effective dose (ED50) i.e. dose at which $50 \%$ of animals were protected against the maximal electroshock induced tonic hind limb extension. ED50 value along with SEM was calculated for various groups by Miller and Tainter method and ED50 of treatment groups were compared with the control group. ${ }^{17-19}$

\section{Phase III}

The study was done using the same study design as in phase II except that AEDs and ADDs were administered daily for 28 days as per Table 1 .

Instrument used for studying seizure activity.

Electroconvulsiometer (Figure 1) was used to determine electroconvulsive threshold and change in ED50 of various AEDs.

To determine effect on seizure activity following methods were used.

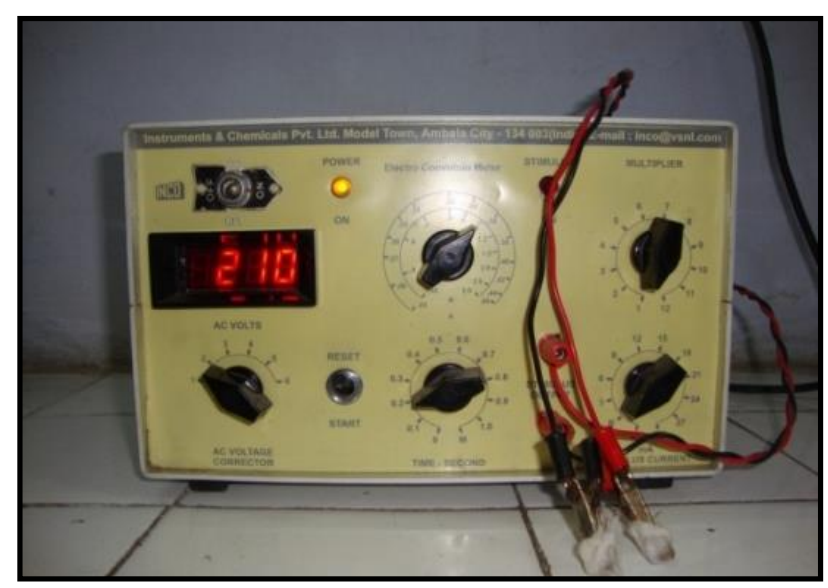

Figure 1: Electroconvulsiometer.

\section{Electroconvulsive threshold method m,11,20 $^{7,}$}

In this test electrical current of various intensity i.e. 6,8 , $10,12 \mathrm{~mA}$ was given to different groups of animals for 0.2 seconds by auricular electrodes using electroconvulsiometer. The minimum current intensity at which tonic hind limb extension (i.e. hind limb of the animal outstretched to 180 degrees to the plane of body axis) (Figure 2) occurred was taken as the electroconvulsive threshold for that animal.

\section{Maximal electroshock seizure (MES) test ${ }^{11,20}$}

In this test each mouse received an electrical stimulus ( $48 \mathrm{~mA})$ for 0.2 seconds via auricular electrodes to induce tonic hind limb extension.

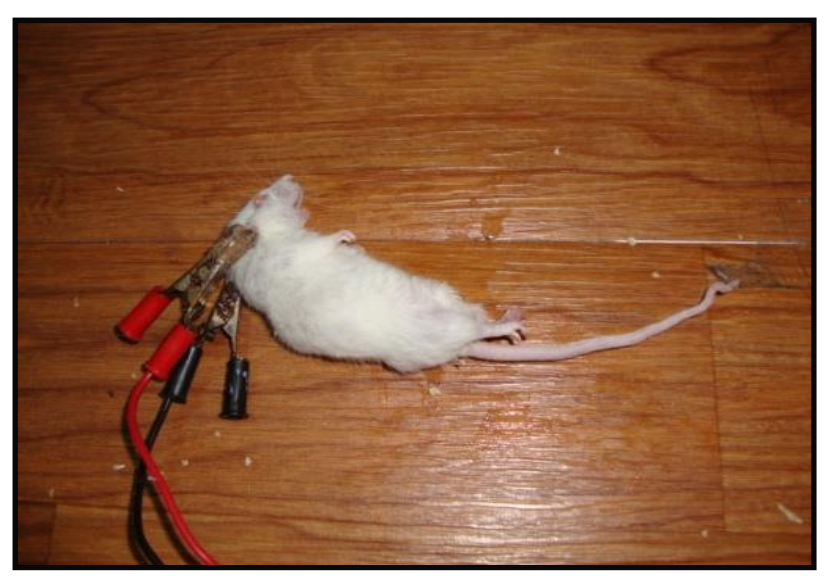

Figure 2: Tonic hind limb extension in mice

\section{Statistical analysis}

Graph Pad® Ver. 6, 32 bit for windows was used for statistical analysis. The statistical analysis of respective CS50 and ED50 values vs. control values was performed with student $t$ test. Results were evaluated at a significance value of $\mathrm{P}$ value $<0.05$.

\section{RESULTS}

\section{Phase I}

Table 2: Effect of the acute treatment with venlafaxine and escitalopram on the electroconvulsive threshold.

\begin{tabular}{|ll|}
\hline Groups & CS 50 \pm SEM (mA) \\
\hline Vehicle (1\% gum acacia) & $6.82 \pm 1.08$ \\
\hline Venlafaxine $(6.25 \mathrm{mg} / \mathrm{kg})$ & $7.3 \pm 1.08$ \\
\hline Venlafaxine $(12.5 \mathrm{mg} / \mathrm{kg})$ & $8.01 \pm 1.04$ \\
\hline Venlafaxine $(25 \mathrm{mg} / \mathrm{kg})$ & $9.50 \pm 0.90 * * *$ \\
\hline Escitalopram $(2 \mathrm{mg} / \mathrm{kg})$ & $6.82 \pm 1.08$ \\
\hline Escitalopram $(4 \mathrm{mg} / \mathrm{kg})$ & $7.3 \pm 1.08$ \\
\hline Escitalopram $(8 \mathrm{mg} / \mathrm{kg})$ & $8.85 \pm 1.08^{* *}$ \\
\hline
\end{tabular}

Values are expressed as mean+standard error of mean (SEM).* denotes $\mathrm{P}<0.05$ in comparison to control, $* *$ denotes $\mathrm{P}<0.01$ in comparison to control, *** denotes $\mathrm{P}<0.001$ in comparison to control

Venlafaxine $25 \mathrm{mg} / \mathrm{kg}$ significantly increased the electroconvulsive threshold from $6.82 \pm 1.08$ to $9.50 \pm 0.85 \mathrm{~mA}$. Whereas venlafaxine given at 6.25 and 
$12.5 \mathrm{mg} / \mathrm{kg}$ increased the CS50 values from $6.82 \pm 1.08$ to $7.3 \pm 1.08$ and $8.01 \pm 1.04 \mathrm{~mA}$ respectively, however these changes were statistically not significant (Table 2). Escitalopram $8 \mathrm{mg} / \mathrm{kg}$ significantly raised the electroconvulsive threshold value from $6.82 \pm 1.08$ to $8.85 \pm 1.08 \mathrm{~mA}$ whereas escitalopram $4 \mathrm{mg} / \mathrm{kg}$ increased the CS50 value from $6.82 \pm 1.08$ to $7.3 \pm 1.08 \mathrm{~mA}$ which was statistically not significant and escitalopram given at $2 \mathrm{mg} / \mathrm{kg}$ did not alter the CS50 value (Table 2).

\section{Phase II}

In phase II, venlafaxine administration at all three doses decreased the ED50 value of valproate in a dose dependent manner. Venlafaxine $6.25,12.5,25 \mathrm{mg} / \mathrm{kg}$ decreased the ED50 of valproate from $237 \pm 45.08$ to $200 \pm 45.08,162.23 \pm 50$ and $127 \pm 48 \mathrm{mg} / \mathrm{kg}$ respectively. Reduction in ED50 values of valproate with administration of 12.5 and $25 \mathrm{mg} / \mathrm{kg}$ of venlafaxine were statistically significant (Table 3).

Table 3: Effect of the acute treatment with venlafaxine and escitalopram on the anticonvulsant action of valproate.

\begin{tabular}{|ll|}
\hline Treatment & ED 50 value \pm SEM $(\mathrm{mg} / \mathrm{kg})$ \\
\hline Valproate+Vehicle & $237 \pm 45.08$ \\
\hline $\begin{array}{l}\text { Valproate+Venlafaxine } \\
(6.25 \mathrm{mg} / \mathrm{kg})\end{array}$ & $200 \pm 45.08$ \\
\hline $\begin{array}{l}\text { Valproate+Venlafaxine } \\
(12.5 \mathrm{mg} / \mathrm{kg})\end{array}$ & $162.23 \pm 50 *$ \\
\hline $\begin{array}{l}\text { Valproate+Venlafaxine } \\
(25 \mathrm{mg} / \mathrm{kg})\end{array}$ & $127 \pm 48^{* *}$ \\
\hline $\begin{array}{l}\text { Valproate+Escitalopram } \\
(2 \mathrm{mg} / \mathrm{kg})\end{array}$ & $237 \pm 45.08$ \\
\hline $\begin{array}{l}\text { Valproate+Escitalopram } \\
(4 \mathrm{mg} / \mathrm{kg})\end{array}$ & $200 \pm 45.08$ \\
\hline $\begin{array}{l}\text { Valproate+Escitalopram } \\
(8 \mathrm{mg} / \mathrm{kg})\end{array}$ & $167.93 \pm 50 *$ \\
\hline
\end{tabular}

Values are expressed as mean+standard error of mean (SEM).* denotes $\mathrm{P}<0.05$ in comparison to control, $* *$ denotes $\mathrm{P}<0.01$ in comparison to control, $* * *$ denotes $\mathrm{P}<0.001$ in comparison to control.

Venlafaxine administered at $6.25,12.5$ and $25 \mathrm{mg} / \mathrm{kg}$ reduced the ED50 of phenobarbitone in a dose dependent manner from $13.19 \pm 4.2$ to $10.0 \pm 4.2,8.82 \pm 3.12$, $8.09 \pm 2.48 \mathrm{mg} / \mathrm{kg}$ respectively. Reduction in ED50 values was statistically significant at $25 \mathrm{mg} / \mathrm{kg}$ of venlafaxine (Table 4). Venlafaxine administered at 12.5 and $25 \mathrm{mg} / \mathrm{kg}$ reduced the ED50 value of phenytoin from $12.74 \pm 3.81$ to $11.09 \pm 4.58$ and $10 \pm 4.8 \mathrm{mg} / \mathrm{kg}$ respectively. However the reduction of ED50 value was not statistically significant. Venlafaxine administered at $6.25 \mathrm{mg} / \mathrm{kg}$ did not affect the ED50 value of phenytoin (Table 5).

Escitalopram administered in the doses of 4 and $8 \mathrm{mg} / \mathrm{kg}$ reduced the ED50 value of valproate from $237 \pm 45.08$ to $200 \pm 45.08$ and $167.93 \pm 50 \mathrm{mg} / \mathrm{kg}$ respectively. Reduction in ED50 value of valproate with co-administration of
$8 \mathrm{mg} / \mathrm{kg}$ escitalopram was statistically significant. Escitalopram given at $2 \mathrm{mg} / \mathrm{kg}$ did not affect the ED50 value of valproate (Table 3 ).

Escitalopram administered in dose of $4 \mathrm{mg} / \mathrm{kg}$ and 8 $\mathrm{mg} / \mathrm{kg}$ reduced the ED50 value of phenobarbitone from $13.19 \pm 4.2$ to $10 \pm 3.8$ and $8.82 \pm 3.12 \mathrm{mg} / \mathrm{kg}$ respectively, which were statistically not significant. Escitalopram given in dose of $2 \mathrm{mg} / \mathrm{kg}$ showed no effect on the ED50 of phenobarbitone (Table 4).

Table 4: Effect of the acute treatment with venlafaxine and escitalopram on the anticonvulsant action of phenobarbitone (PB).

\begin{tabular}{|ll|}
\hline Treatment & $\begin{array}{l}\text { ED 50 value } \pm \text { SEM } \\
(\mathrm{mg} / \mathrm{kg})\end{array}$ \\
\hline Phenobarbitone+Vehicle & $13.19 \pm 4.2$ \\
\hline $\begin{array}{l}\text { Phenobarbitone+Venlafaxine } \\
(6.25 \mathrm{mg} / \mathrm{kg})\end{array}$ & $10.0 \pm 4.2$ \\
\hline $\begin{array}{l}\text { Phenobarbitone+Venlafaxine } \\
(12.5 \mathrm{mg} / \mathrm{kg})\end{array}$ & $8.82 \pm 3.12$ \\
\hline $\begin{array}{l}\text { Phenobarbitone+Venlafaxine } \\
(25 \mathrm{mg} / \mathrm{kg})\end{array}$ & $8.09 \pm 2.48 *$ \\
\hline $\begin{array}{l}\text { Phenobarbitone+Escitalopram } \\
(2 \mathrm{mg} / \mathrm{kg})\end{array}$ & $13.19 \pm 4.2$ \\
\hline $\begin{array}{l}\text { Phenobarbitone+Escitalopram } \\
(4 \mathrm{mg} / \mathrm{kg})\end{array}$ & $10 \pm 3.8$ \\
\hline $\begin{array}{l}\text { Phenobarbitone+Escitalopram } \\
(8 \mathrm{mg} / \mathrm{kg})\end{array}$ & $8.82 \pm 3.12$ \\
\hline $\begin{array}{l}\text { Values are expressed as mean+standard error of mean }(\mathrm{SEM}) * \\
\text { denotes } \mathrm{P}<0.05 \text { in comparison to control, } * * \text { denotes } \mathrm{P}<0.01 \text { in } \\
\text { comparison to control, } * * * \text { denotes } \mathrm{P}<0.001 \text { in comparison to } \\
\text { control. }\end{array}$
\end{tabular}

Table 5: Effect of the acute treatment with venlafaxine and escitalopram on the anticonvulsant action of phenytoin.

\begin{tabular}{|ll|}
\hline Treatment & $\begin{array}{l}\text { ED 50 value } \pm \text { SEM } \\
(\mathrm{mg} / \mathrm{kg})\end{array}$ \\
\hline Phenytoin+Vehicle & $12.74 \pm 3.81$ \\
\hline $\begin{array}{l}\text { Phenytoin+Venlafaxine } \\
(6.2 \mathrm{mg} / \mathrm{kg})\end{array}$ & $12.74 \pm 3.81$ \\
\hline $\begin{array}{l}\text { Phenytoin+Venlafaxine } \\
(12.5 \mathrm{mg} / \mathrm{kg})\end{array}$ & $11.09 \pm 4.58$ \\
\hline $\begin{array}{l}\text { Phenytoin+Venlafaxine } \\
(25 \mathrm{mg} / \mathrm{kg})\end{array}$ & $10 \pm 4.8$ \\
\hline $\begin{array}{l}\text { Phenytoin+Escitalopram } \\
(2 \mathrm{mg} / \mathrm{kg})\end{array}$ & $12.74 \pm 3.81$ \\
\hline $\begin{array}{l}\text { Phenytoin+Escitalopram } \\
(4 \mathrm{mg} / \mathrm{kg})\end{array}$ & $11.09 \pm 4.58$ \\
\hline $\begin{array}{l}\text { Phenytoin+Escitalopram } \\
(8 \mathrm{mg} / \mathrm{kg})\end{array}$ & $10 \pm 3.11$ \\
\hline
\end{tabular}

Values are expressed as mean+standard error of mean (SEM).* denotes $\mathrm{P}<0.05$ in comparison to control, $* *$ denotes $\mathrm{P}<0.01$ in comparison to control, $* * *$ denotes $\mathrm{P}<0.001$ in comparison to control. 
Escitalopram given in doses of 4 and $8 \mathrm{mg} / \mathrm{kg}$ reduced the ED50 value of phenytoin from $12.74 \pm 3.81$ to $11.09 \pm 4.58$ and $10 \pm 3.11 \mathrm{mg} / \mathrm{kg}$ respectively; however, these reductions in ED50 values were statistically not significant. Escitalopram given in dose of $2 \mathrm{mg} / \mathrm{kg}$ had no effect on ED50 value of phenytoin (Table 5).

\section{Phase III}

Venlafaxine given in doses of $6.25,12.5$ and $25 \mathrm{mg} / \mathrm{kg}$ reduced the ED50 Value of valproate in dose dependent manner from $237 \pm 45.08$ to $200 \pm 45.08,142.94 \pm 45.92$ and $100 \pm 23.30 \mathrm{mg} / \mathrm{kg}$ respectively, the reductions in ED50 value of valproate at 12.5 and $25 \mathrm{mg} / \mathrm{kg}$ was statistically significant (Table 6). Venlafaxine given at dose 6.25, 12.5 , and $25 \mathrm{mg} / \mathrm{kg}$ reduced the ED 50 value of phenobarbitone from $13.19 \pm 4.2 \mathrm{mg} / \mathrm{kg}$ to $10 \pm 4,8.82 \pm 3.12$ and $8.01 \pm 2.65 \mathrm{mg} / \mathrm{kg}$ respectively. The reduction in ED50 value with venlafaxine $25 \mathrm{mg} / \mathrm{kg}$ was found to be statistically significant (Table 7).

Table 6: Effect of the chronic treatment with venlafaxine and escitalopram on the anticonvulsant action of valproic acid.

\begin{tabular}{|ll|}
\hline Treatment & ED 50 value \pm SEM $(\mathrm{mg} / \mathrm{kg})$ \\
\hline Valproate+Vehicle & $237 \pm 45.08$ \\
\hline $\begin{array}{l}\text { Valproate+Venlafaxine } \\
(6.25 \mathrm{mg} / \mathrm{kg})\end{array}$ & $200 \pm 45.08$ \\
\hline $\begin{array}{l}\text { Valproate+Venlafaxine } \\
(12.5 \mathrm{mg} / \mathrm{kg})\end{array}$ & $142.94 \pm 45.92 * *$ \\
\hline $\begin{array}{l}\text { Valproate+Venlafaxine } \\
(25 \mathrm{mg} / \mathrm{kg})\end{array}$ & $100 \pm 23.30 * * *$ \\
\hline $\begin{array}{l}\text { Valproate+Escitalopram } \\
(2 \mathrm{mg} / \mathrm{kg})\end{array}$ & $237 \pm 45.08$ \\
\hline $\begin{array}{l}\text { Valproate+Escitalopram } \\
(4 \mathrm{mg} / \mathrm{kg})\end{array}$ & $200 \pm 45.08$ \\
\hline $\begin{array}{l}\text { Valproate+Escitalopram } \\
(8 \mathrm{mg} / \mathrm{kg})\end{array}$ & $131.84 \pm 51.48 * *$ \\
\hline
\end{tabular}

Values are expressed as mean + standard error of mean (SEM).* denotes $\mathrm{P}<0.05$ in comparison to control, ** denotes $\mathrm{P}<0.01$ in comparison to control, $* * *$ denotes $\mathrm{P}<0.001$ in comparison to control

Venlafaxine administered at dose of $6.25,12.5$ and $25 \mathrm{mg} / \mathrm{kg}$ reduced the ED50 of phenytoin from $12.74 \pm 3.81$ to $11.09 \pm 3.81,10 \pm 3.11$ and $8.09 \pm 2.46 \mathrm{mg} / \mathrm{kg}$ respectively, the reduction in ED50 value of phenytoin with venlafaxine $25 \mathrm{mg} / \mathrm{kg}$ was statistically significant (Table 8). Escitalopram given in dose of 4 and $8 \mathrm{mg} / \mathrm{kg}$ reduced the ED50 value of valproate from $237 \pm 45.08$ to $200 \pm 45.08$ and $131.84 \pm 51.48 \mathrm{mg} / \mathrm{kg}$ respectively. The reduction in ED50 value of valproate with $8 \mathrm{mg} / \mathrm{kg}$ of escitalopram was statistically significant. Escitalopram given at $2 \mathrm{mg} / \mathrm{kg}$ had no effect on the ED50 value of valproate (Table 6).

Escitalopram administered chronically in doses of 4 and 8 $\mathrm{mg} / \mathrm{kg}$ reduced the ED50 values of phenobarbitone from $13.19 \pm 4.2$ to $10 \pm 4.2$ and $8.82 \pm 3.12 \mathrm{mg} / \mathrm{kg}$ respectively, however these reductions in ED50 values were statistically not significant. Escitalopram given in dose of $2 \mathrm{mg} / \mathrm{kg}$ did not influence the ED50 value of phenobarbitone (Table 7).

Table 7: Effect of the chronic treatment with venlafaxine and escitalopram on the anticonvulsant action of phenobarbitone.

\begin{tabular}{|ll|}
\hline Treatment & $\begin{array}{l}\text { ED 50 value } \pm \text { SEM } \\
(\mathrm{mg} / \mathrm{kg})\end{array}$ \\
\hline Phenobarbitone+Vehicle & $13.19 \pm 4.2$ \\
\hline $\begin{array}{l}\text { Phenobarbitone+ } \\
\text { Venlafaxine }(6.25 \mathrm{mg} / \mathrm{kg})\end{array}$ & $10 \pm 4.2$ \\
\hline $\begin{array}{l}\text { Phenobarbitone+ } \\
\text { Venlafaxine }(12.5 \mathrm{mg} / \mathrm{kg})\end{array}$ & $8.82 \pm 3.12$ \\
\hline $\begin{array}{l}\text { Phenobarbitone+ } \\
\text { Venlafaxine }(25 \mathrm{mg} / \mathrm{kg})\end{array}$ & $8.01 \pm 2.65^{*}$ \\
\hline $\begin{array}{l}\text { Phenobarbitone+ } \\
\text { Escitalopram }(2 \mathrm{mg} / \mathrm{kg})\end{array}$ & $13.19 \pm 4.2$ \\
\hline $\begin{array}{l}\text { Phenobarbitone+ } \\
\text { Escitalopram }(4 \mathrm{mg} / \mathrm{kg})\end{array}$ & $10 \pm 4.2$ \\
\hline $\begin{array}{l}\text { Phenobarbitone+ } \\
\text { Escitalopram }(8 \mathrm{mg} / \mathrm{kg})\end{array}$ & $8.82 \pm 3.12$ \\
\hline
\end{tabular}

Values are expressed as mean + standard error of mean (SEM).* denotes $\mathrm{P}<0.05$ in comparison to control, $* *$ denotes $\mathrm{P}<0.01$ in comparison to control, $* * *$ denotes $\mathrm{P}<0.001$ in comparison to control.

Escitalopram given in doses of 4 and $8 \mathrm{mg} / \mathrm{kg}$ reduced the ED50 values of phenytoin from $12.74 \pm 3.81$ to $11.09 \pm 4.58$ and $10 \pm 3.11 \mathrm{mg} / \mathrm{kg}$ respectively. The reduction in both these ED50 value were not significant statistically. Escitalopram given in $2 \mathrm{mg} / \mathrm{kg}$ did not influence the ED50 value of phenytoin (Table 8).

Table 8: Effect of the chronic treatment with venlafaxine and escitalopram on the anticonvulsant action of phenytoin.

\begin{tabular}{|ll|}
\hline Treatment & ED 50 value \pm SEM $(\mathrm{mg} / \mathrm{kg})$ \\
\hline Phenytoin+Vehicle & $12.74 \pm 3.81$ \\
\hline $\begin{array}{l}\text { Phenytoin+Venlafaxine } \\
(6.2 \mathrm{mg} / \mathrm{kg})\end{array}$ & $11.09 \pm 3.81$ \\
\hline $\begin{array}{l}\text { Phenytoin+Venlafaxine } \\
(12.5 \mathrm{mg} / \mathrm{kg})\end{array}$ & $10 \pm 3.11$ \\
\hline $\begin{array}{l}\text { Phenytoin+Venlafaxine } \\
(25 \mathrm{mg} / \mathrm{kg})\end{array}$ & $8.09 \pm 2.46 *$ \\
\hline $\begin{array}{l}\text { Phenytoin+Escitalopram } \\
(2 \mathrm{mg} / \mathrm{kg})\end{array}$ & $12.74 \pm 3.81$ \\
\hline $\begin{array}{l}\text { Phenytoin+Escitalopram } \\
(4 \mathrm{mg} / \mathrm{kg})\end{array}$ & $11.09 \pm 4.58$ \\
\hline $\begin{array}{l}\text { Phenytoin+Escitalopram } \\
(8 \mathrm{mg} / \mathrm{kg})\end{array}$ & $10 \pm 3.11$ \\
\hline
\end{tabular}

Values are expressed as mean + standard error of mean (SEM).* denotes $\mathrm{P}<0.05$ in comparison to control, ** denotes $\mathrm{P}<0.01$ in comparison to control, $* * *$ denotes $\mathrm{P}<0.001$ in comparison to control. 


\section{DISCUSSION}

Venlafaxine, a SNRI, blocks reuptake of noradrenaline (NA) and serotonin (5-HT) and also has direct action on 5-HT1A and $\beta 2$ receptors, without any significant effect on cholinergic and histaminergic receptors. Increase in synaptic concentration of NA and 5-HT has been demonstrated to exert its anticonvulsant and antidepressant activity. ${ }^{21}$

It has been demonstrated that increase in NA levels in brain control GABA, glutamate, and dopamine levels through $\alpha$ and $\beta 2$ receptors and is responsible for decrease in seizure activity. ${ }^{22,23}$ Serotonergic transmission has been postulated to modulate seizure activity by decreasing excitatory and increasing the inhibitory activity due to hyperpolarization of glutamatergic neurons by 5-HT1A receptors and depolarization of GABAergic neurons by 5 -HT2C receptors, respectively. ${ }^{24}$ As seen with fluoxetine, chronic administration of venlafaxine has also been shown to elevate brain concentration of inhibitory neurosteroid allopregnanolone which is a potent positive modulator of GABAA receptors. ${ }^{7,11}$ Elevation in allopregnanolone may also be contributing to anticonvulsant effects of venlafaxine. Thirdly, effect of SSRIs such as inhibition of production of pro- inflammatory cytokines like interleukin $1 \beta$, tumor necrosis factor $\alpha$ and interferon $\gamma$ and increase in antiinflammatory cytokines such as interleukin-10 may also be another mechanism for anticonvulsant effect of venlafaxine as pro inflammatory cytokines are involved in generating and exacerbating seizures. ${ }^{25,26}$ The contribution of change in levels of venlafaxine or studied AEDs cannot be ruled. In an earlier study, it has been observed that venlafaxine does not change the levels of valproate in brain on acute and chronic administration at the doses administered in this study though these doses have been found to raise the levels of phenobarbitone on acute administration, but lower that of phenytoin on chronic administration in this study. ${ }^{11}$ The least effect on ED50 of phenytoin with venlafaxine in this study may be explained by lowering of phenytoin concentration in brain.

Escitalopram, S-enantiomer of the citalopram and a SSRI, increased the electroconvulsive threshold in dose dependent manner but significantly at a dose of $8 \mathrm{mg} / \mathrm{kg}$. On acute and chronic administration of escitalopram in combination with studied AEDs, significant reduction in ED50 of valproate was observed at $8 \mathrm{mg} / \mathrm{kg}$ with no significant change in ED50 of phenobarbitone and phenytoin. The anticonvulsant activity of escitalopram can be explained by the elevation of serotonin concentration in synapses as above. In the present study, it was revealed that venlafaxine and escitalopram administered either alone or in combination with antiepileptics acutely or chronically, exhibit anticonvulsant action.

\section{CONCLUSION}

From the above findings, it may be concluded that venlafaxine and escitalopram administered either alone or in combination with AEDs acutely or chronically, exhibit anticonvulsant action. These findings suggest that both of these antidepressants may be given safely in patients of epilepsy suffering from depression. However, the study is experimental in nature and requires further studies.

Funding: No funding sources

Conflict of interest: None declared

Ethical approval: The study was approved by the Institutional Animal Ethics Committee

\section{REFERENCES}

1. Ebert U. Basic mechanisms of psychotropic drugs. Epilepsia. 2002;43(s2):2-7.

2. Mula M, Schmitz B. Review: Depression in epilepsy: mechanisms and therapeutic approach. Therapeutic advances in neurological disorders. 2009;2(5):33744.

3. Cardamone L, Salzberg M, O'Brien T, Jones N. Antidepressant therapy in epilepsy: can treating the comorbidities affect the underlying disorder? British journal of pharmacology. 2013;168(7):1531-54.

4. Dailey JW, Naritoku DK. Antidepressants and seizures: clinical anecdotes overshadow neuroscience. Biochemical pharmacology. 1996;52(9):1323-9.

5. Pisani F, Spina E, Oteri G. Antidepressant drugs and seizure susceptibility: from in vitro data to clinical practice. Epilepsia. 1999;40(10):S48-56.

6. Borowicz KK, Stêpieñ K, Czuczwar Sa J. Fluoxetine enhances the anticonvulsant effects of conventional antiepileptic drugs in maximal electroshock seizures in mice. Pharmacological reports. 2006;58(1):83.

7. Borowicz KK, Furmanek-Karwowska K, Sawicka K, Luszczki JJ, Czuczwar SJ. Chronically administered fluoxetine enhances the anticonvulsant activity of conventional antiepileptic drugs in the mouse maximal electroshock model. Eur $\mathbf{J}$ of Pha. 2007;567(1):77-82.

8. Raju S, Noor A, Gurthu S, Giriyappanavar C, Acharya S, Low $\mathrm{H}$, et al. Effect of fluoxetine on maximal electroshock seizures in mice: acute vs chronic administration. Pharmacological research. 1999;39(6):451-4.

9. Borowicz KK, Banach M, Zarczuk R, Lukasik D, Luszczki JJ, Czuczwar SJ. Acute and chronic treatment with mianserin differentially affects the anticonvulsant activity of conventional antiepileptic drugs in the mouse maximal electroshock model. Psychopharmacology. 2007;195(2):167-74.

10. Kumar M. A study on effect of trazadone, amoxapine and venlafaxine on MES (maximal electroshock) induced seizures in albino rats.

11. Borowicz KK, Gołyska D, Luszczki JJ, Czuczwar SJ. Effect of acutely and chronically administered 
venlafaxine on the anticonvulsant action of classical antiepileptic drugs in the mouse maximal electroshock model. Eur J of Pha. 2011;670(1):11420.

12. Aricioglu F, Salanturoglu G, Buldanlioglu U, Ozyalcin S. Effect of venlafaxine on maximal electroshock induced seizures in mice. Annals of General Psychiatry. 2006 Feb 1;5(S1):S103.

13. Santos Junior J, Do Monte F, Russi M, Agustine P, Lanziotti V. Proconvulsant effects of high doses of venlafaxine in pentylenetetrazole-convulsive rats. Brazilian journal of medical and biological research. 2002;35(4):469-72.

14. Favale E, Audenino D, Cocito L, Albano C. The anticonvulsant effect of citalopram as an indirect evidence of serotonergic impairment in human epileptogenesis. Seizure: The $\mathbf{J}$ of the British Epilepsy Association. 2003;12(5):316-8.

15. Bahremand A, Payandemehr B, Rahimian R, Ziai P, Pourmand N, Loloee S, et al. The role of 5-HT 3 receptors in the additive anticonvulsant effects of citalopram and morphine on pentylenetetrazoleinduced clonic seizures in mice. Epilepsy and Behavior. 2011;21(2):122-7.

16. Care V. CPCSEA Guidelines for laboratory animal facility. Indian Journal of Pharmacology. 2003;35:257-74.

17. Randhawa MA. Calculation of LD50 values from the method of Miller and Tainter, 1944. Journal of Ayub Medical College, Abbottabad: JAMC. 2009;21(3):184-5.

18. Gupta D, Bhardwaj S. Study of Acute, Subacute and Chronic Toxicity Test. Int J Cur Biomed Phar Res. 2012;2(2):290-89.

19. Turner R, Quantal responses. Calculation of ED50. In Screening Methods in Pharmacology, Academic Press, New York; 1965:61-63.

20. Castel-Branco MM, Alves GL, Figueiredo IV, Falcao AC, Caramona MM. The maximal electroshock seizure (MES) model in the preclinical assessment of potential new antiepileptic drugs. Methods and findings in experimental and clinical pharmacology. 2009;31(2):101-6.

21. Jobe PC. Common pathogenic mechanisms between depression and epilepsy: an experimental perspective. Epilepsy and behavior. 2003;4(3):S14-24.

22. Jobe PC. Affective disorder and epilepsy comorbidity: implications for development of treatments, preventions and diagnostic approaches. Clinical EEG and neuroscience: Official Journal of the EEG and Clinical Neuroscience Society. 2004;35(1):53-68.

23. Clinckers R, Zgavc T, Vermoesen K, Meurs A, Michotte Y, Smolders I. Pharmacological and neurochemical characterization of the involvement of hippocampal adrenoreceptor subtypes in the modulation of acute limbic seizures. Journal of Neurochemistry. 2010;115(6):1595-607.

24. Vermoesen K, Massie A, Smolders I, Clinckers R. The antidepressants citalopram and reboxetine reduce seizure frequency in rats with chronic epilepsy. Epilepsia. 2012;53(5):870-8.

25. Maroso M, Balosso S, Ravizza T, Liu J, Aronica E, Iyer AM, et al. Toll-like receptor 4 and high-mobility group box-1 are involved in ictogenesis and can be targeted to reduce seizures. Nature medicine. 2010;16(4):413-9.

26. Vezzani A, Moneta D, Conti M, Richichi C, Ravizza $\mathrm{T}$, De Luigi A, et al. Powerful anticonvulsant action of IL-1 receptor antagonist on intracerebral injection and astrocytic overexpression in mice. Proceedings of the National Academy of Sciences. 2000;97(21):11534-9.

Cite this article as: Singh $\mathrm{SK}$, Singh $\mathrm{A}$. An experimental study to investigate the effects of venlafaxine and escitalopram on anticonvulsant activity of conventional antiepileptic drugs in mice. Int J Basic Clin Pharmacol 2017;6:1701-7. 